Titchener and myself apropos of his article in ScIENCE for December 23d (Vol. VIII., p. 897).

Messrs. Lehmann and Hansen had sought to show experimentally that the results of certain experiments by Professor H. Sidgwick, which the latter had ascribed to 'thought-transference,' were really due to involuntary whispering by the agent, overheard hyperæsthetically by the subjects. Professor Titchener closed his article by saying: "The brilliant work of Messrs. L. and $H$. has probably done more for scientific psychology than could have been accomplished by any aloofness, however authoritative."

To these words I, in your next number, took exception, saying that if Professor Titchener would read Sidgwick's and my criticisms of the work of the Danish investigators, he would probably agree 'that, owing to the fewness of the data which they had collected, they entirely failed to prove their point.' I, consequently, called their essay 'an exploded document'; to which my 'scientifically-minded' confrère rejoined (in ScIENCE for January 6th) that he had carefully read the criticisms, and had thus seen us ' handling the fuse,' but that he had 'not yet heard the detonation.'

As the explosion was so audible to me, the disproof being quasi-mathematical, I was astounded at this hardness of hearing in my colleague; and, to make sure that I was not a victim of auditory hallucination, I wrote to Professor Lehmann to know what he himself thought of his conclusions, in the light of the criticisms in question. His answer, somewhat belated, just arrives.

He says : "Your own as well as Professor Sidgwick's experiments and computations prove, beyond a doubt, that the play of chance had thrown into my hands a result distinctly too favorable to my theory, and that the said theory is consequently not yet established (bewiesen)."

This is identically Professor Sidgwick's and my contention; and for his candor, as well as for his willingness to take pains to experiment in this region, Professor Lehmann deserves to stand high as a 'psychical researcher.'

Professor Titchener, meanwhile, still hugging the exploded document, wanders upon what he calls ' the straight scientific path,' having it apparently all to himself. May the consciousness of his fidelity to correct scientist principles console him in some degree both for his deafness and for his isolation.

$$
\text { Cambridge, April 20, 1899. William James. }
$$

\section{TWO CORRECTIONS.}

MY attention has just been called to this paragraph in ScIEnce, June 3, 1898, p. 784, foot of column two :

"Erratum: In the review of Wilder's System of Nomenclature, p. 716, col. I, line 5, for ' chippocamp' read 'hippocamp.'"

This prompt public correction renders needless and unjust the commentary upon the subject in my address last December before the Association of American Anatomists (Proceedings, p. 33, and ScIENCE, April 21, 1899, p. 577), and I deplore my non-acquaintance with it up to the present time. Since none of those who heard my address reminded me of the 'Erratum,' it seems to have been overlooked by them also.

In this connection may properly be corrected a typographical error in the address itself (Proceedings, p. 16, and SCIENCE, April 21, 1899 , p. 566, note, title 6 ); the date of publication of the 'Review' in ScIence should be May 20th, not 28th.

These corrections will be incorporated in the Proceedings and sent to those who receive copies. of Science from me.

B. G. WILDER.

ITHACA, N. Y., April 26, 1899.

[It may be explained the typographical error. referred to above was not due to any oversight on the part of the writer of the review. An inverted comma (') was inserted in the proof' before hippocamp, which was mistaken by the printer and the proof reader for a c.-ED. SCIENCE.]

\section{NOTES ON PHYSICS.}

A NEW THEORY OF THE ZEEMAN EFFECT.

DURING the last eight or ten years Goldhammer has published at intervals in Wiedemann's Annalen a series of papers dealing with the electro-magnetic theory of light, and espe- 